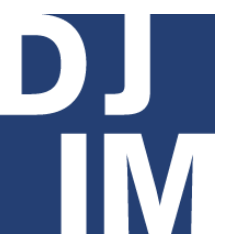

Volume 13

Spring

2017

djim.management.dal.ca |

\title{
The Rise of Populist Conservatism and Public Service Management
}

Nicole Saulnier

School of Public Administration, Dalhousie University

\begin{abstract}
The rise of conservative populism in Canada is evident with the election of Stephen Harper and the Conservative leadership race. Aspects of those campaigns are focused on a fear of otherness, a resentment of elites (including bureaucrats), and an emphasis on self-interest. This paper will focus on populist policies and actions introduced during Stephen Harper's tenure in government. Many of these policies were directed specifically towards the public service including the reduction of public servants, unilateral changes to labour laws, and the politicization of the public service through a proposed niqab ban. While the influence of populist conservative policies caused noticeable resentments between public servants and the Conservative Party, public servants should reconsider their position within democracy as not focused on their compatibility with the government of the day, but rather with their adherence to the values of inclusion, fairness, and neutrality. The public service must constantly adapt to the will of the political branch of government including more populist governments; however these core values should be celebrated through active implementation and leadership to aid in the development of a positive relationship with both the political arm of government and the public more broadly. These values provide a means for individual public servants to invest their motivation into values that they can treat as fundamental to their role in democracy.
\end{abstract}

\section{Issue and Background}

The rise of the populist right began in the 1970s and 1980s; however, with the 20062015 federal government and the 2017 Conservative Party leadership race, there is a sudden reoccurrence of its popularity within twenty-first century political culture. The following analysis will focus on the rise of the conservative populist movement with its focus on a fear of otherness, a resentment of elites (including bureaucrats), and an emphasis on self-interest, which is reflected noticeably in Stephen Harper's Conservative government's policies throughout its tenure in government. Many of these policies were 
directed specifically towards the public service including the reduction of public servants, unilateral changes to labour laws, and the politicization of the public service through a proposed niqab ban. While the influence of populist conservatism has caused noticeable resentments between public servants and the Conservative Party, public servants should reconsider their position within democracy as not focused on their compatibility with the government of the day, but rather with their adherence to the values of inclusion, fairness, and neutrality. While the public service must constantly adapt to the will of the political branch of government including more populist governments, these core values should be celebrated through active implementation and leadership to aid in the development of a positive relationship with both the political arm of government and the public more broadly. These values provide a means for individual public servants to invest their motivation into values that they can treat as fundamental to their role in democracy.

\section{Canadian Conservatism}

The rise of the populist right began in the 1970s and 1980s in North America and Europe with a focus on legitimizing a corrupt system and protecting the needs of "the people." Betz and Johnson (2004) outline the fundamental aspects of radical right populism that arose after the Cold War. They argue that this type of populism demonstrates "radical type of right-wing populism, whose proponents seek to transform liberal democracy into an ethnocratic regime, which gives supremacy to the interests of 'the people,' defined in terms of a narrow conception of citizenship" (Betz $\&$ J ohnson, 2004, p. 313). This type of radicalism embraces both liberal democracy and radical ideals seeking to protect democracy from threats. Most importantly, at the centre of this ideology is "the charge that in liberal capitalist democracies power has been usurped by a self-serving political and cultural elite that pursues its own narrow agenda without concern for the [legitimate] concerns and interests of ordinary citizens" (Betz \& J ohnson, 2004, p. 313). This concern clearly demonstrates the grassroots nature of the populist movement, which does not see itself within the political elites. The radical right appeals to the "common sense of ordinary people" (Betz \& Johnson, 2004, p. 315), in order to advance its agenda protesting the corruption of democracy. A large component of the populist right is identity politics serving to justify "selective exclusion," which emphasizes assimilation of minorities and fear of otherness (Betz \& Johnson, 2004, p. 318-319). The radical rhetoric of the populist right has risen throughout the late twentieth and early twenty-first century to a form of legitimacy within many liberal democracies.

In Canada, the rise of the Conservative Party and Stephen Harper has distinct elements related to the radical, populist right movement of the 1970s and 1980s. The rise of the Conservative Party in 2006-2015 redefined conservativism at the level of formal political parties. The populist movement in Canada is most visible within the Reform Party, which looked to "reengage and re-energize democratic life" through promises such as reforming the Senate, relaxed party discipline, and greater transparency (Farney, 2013, p. 44). These sentiments greatly resonated with Canadian populist conservatives who were looking for an alternative to Brian Mulroney's conservativism. Most surprisingly, the federal Conservatives have become very capable at "integrating these populist 
appeals with conservatism in a way that, rather than seeming radical and challenging...seems commonsensical and moderate to enough Canadians to form a government" (Farney, 2013, p. 45). However, the rise of populism also led to aspects of the federal Conservative Party that go against the traditional ideals of populist conservatism. According to Farney (2013), it is striking that the Conservative Party contradicts the very ideals of populism through its centralization of power in the Prime Minister's Office and the overall professionalization of the party's organization. This may have led to the party's recent defeat and the rise of the rhetoric of Canadian values and political elites within the current Conservative leadership race.

While Canadians consider themselves more open and tolerant of diversity through multiculturalism and immigration, the rise of conservative populism in recent years somewhat contradicts this long-held belief. The increase in individual self-interested behaviour and rhetoric fueled the rise of populism, which led to dissatisfaction with the status quo of political and cultural phenomenon. Hay (2011) notes that, while the identification of individual interests and motivations may seem straightforward, this is not the case due to the complexity of human experience and knowledge. The author argues that individuals' interests in themselves and their needs do not truly exist because they are a construction of interests. These constructions are an "inherently normative and subjective" conception of selfgood and though this conception arises "out of an ongoing interaction with" a context, conceptions "are neither given or determined by the context nor" individual's knowledge (Hay, 2011, p. 79). This perception of selfinterest is reflected in individual beliefs, especially amongst those who identify with populist movements. The idea of populism as a construction of self-interest is important for political and public service leaders to consider when interacting with its symptoms of racism and ethnocentrism.

The construction of self-interest within the conservative populist movement created a racially-driven culture including ethnocentric tendencies with a rhetoric of a self-interested "us" and a threatening "them." As Winter (2015) notes, Canadians pride themselves on their acceptance of multiculturalism, but they include certain groups into the construction of the "multicultural we" while excluding others (p. 641). Through an analysis of articles and speeches by the former Minister of Immigration, Citizenship and Multiculturalism, Jason Kenney, between 2008 and 2013, Winter (2015) studies the Conservative Party speeches and press releases on belonging and immigration where she finds a reinvention of immigration and multiculturalism. The author notes in her analysis that "in practice, Canadian multiculturalism...never really conceive[d] of White Anglo-Saxons as "just another ethnic group"' (Winter, 2015, p. 651). With the reinvention of multiculturalism in the 2000s, around the same time as the rise of populist conservatism, White Anglo-Saxons are "even stronger and officially identified with British traditions, values, and institutions such as the monarchy. In fact, Kenney portrays integrative pluralism as a 'British liberal imperial tradition"' (Winter, 2015, p. 651). This reconstruction of the perception of Canadian identity surrounding multiculturalism is key to the populist movement that focuses on the construction of an Anglo-Saxon "us" and a non-AngloSaxon "them." For example, a poll by the Canadian Broadcasting Corporation (CBC) 
and the Angus Reid Institute found that $68 \%$ of Canadian respondents believe that minorities should be doing more to integrate into society rather than maintaining their own culture and customs (Proctor, 2016, n.p.) demonstrating that this rhetoric is permeating into mainstream society. This construction of otherness creates a retreat in the tolerance of difference within Canadian society and, especially, within the Conservative Party of Canada.

\section{The Public Service}

\section{Public Service and Populism}

The rise of populism within the Conservative Party illustrates through the party's interactions and policies regarding the public service. The members of the right-wing populist movement include members of the middle class who believe they are being attacked by special interest groups and that those who succeed in the current, unsatisfactory system are civil servants, journalists, judges, established political parties, and progressives (Farney, 2013). During its time in government, the federal Conservative Party controlled and censured the public service especially when findings or evidence contradicted party policies or directions. The populist sentiment of resentment and distrust towards the public service is noticeable in the ways that the populist movement treats the public service's work on policy development and service delivery as well as the difficult employeremployee relationship between the Conservative Party and public servants. In some ways, these interactions threatened the public service's autonomy and anonymity from the political side of government and the public.

\section{Conservative Party and the Public Service}

The Conservative Party's lack of acceptance and censuring of public servant's findings and work demonstrates the populist distrust of the public service elite. Most notably, Stephen Harper's government repeatedly attacked "public servants for partisan ends, [it muzzled] government scientists, [and it willfully dismissed] bureaucratic evidence and advice" (Freeman, 2015, n.p.). This treatment of the public service results in a threat to the public service's autonomy by its political masters. Furthermore, the quality of work that the public service is able to present and discuss with its political masters is diminished as there is less confidence that the public service's work is being considered during decision-making.

The types of policies the government attempted, and sometimes succeeded, in enforcing on public servants demonstrates the lack of respect held by the governing party for the work achieved by public servants. The populist conservative's belief in a smaller, efficient government is noticeable in the Conservative Party's treatment of public servant positions throughout its tenure in office. The Conservative government led by Stephen Harper is well known for cutting the numbers of public servants under the pretense of removing unnecessary drains on the government system. According to the Centre for Policy Alternatives, as of November 2014, the Conservative government had removed 37,000 employees from the public service payroll (May, 2014, n.p.). The Centre suggested that the rush to balance the federal budget resulted in cuts to frontline service delivery functions performed by public servants with Veterans Affairs expected to lose approximately $32 \%$ of its 
workforce between 2011 and 2017 (May, 2014 , n.p.). The downsizing of the public service by government at such drastic levels also increased the level of resentment by public servants towards the government, as demonstrated through organized labour who continuously opposed specific labour policies. For example, the government unilaterally amended the Public Service Labour Act to replace the sick leave program, which removed the ability to bank sick days from year to year (Tasker, 2016). This move angered public servants who saw it as disrespectful of the collective bargaining process and employee rights. The publicsector unions mounted an opposition to changes in sick day leave and, as of December 2016, have agreed with the federal government to maintain current sick days while a task force tries to negotiate a new agreement (May, 2016, n.p.).

The Conservative government further tried to appeal to its populist roots during the election by suggesting the introduction of public service management policy that specifically targeted one religious sector of the population. During a campaign stop in Saskatoon, P rime Minister Harper stated that if he were elected to another term, he would consider a federal law banning the niqab in the federal public service (May \& MacLeod, 2015). The Conservative Party suggested this policy in order to gain support from the ethnocentric populist conservatives by using the rhetoric of "us" and "them" and referencing the anti-Muslim rhetoric of the populist movement. The government attempted to discuss this issue by suggesting that Muslim women's choice to wear the niqab is anti-woman and discriminatory, which again plays into the idea of protecting liberal democratic institutions while preserving White Anglo-Saxon values.

\section{Conflicting Values}

The biggest issue arising from the resentment between the populist Conservative Party and the Canadian public service is the conflicting values in the very essence of their construction. The discussion demonstrates that populist conservatives resent and distrust special interests, religious/ethnic minorities, and bureaucrats. In many ways, these values and concerns contradict the fundamental aspects of the public service including service delivery to special interest groups (Indigenous peoples, refugees); protection of religious and ethnic minorities (enforcement of section 2 of the Charter of Rights and Freedoms); and anonymity of the public service. The very construction of the populist movement, which favours direct democracy, protection of Anglo-Saxon culture, and cutting of government, is contradictory to the public service institution premised on equity, fairness, and neutrality in the delivery of government services. However, the public service values and actions demonstrate that the public service must deliver services to all citizens (and some residents) in Canada to fulfill its fundamental role in the democratic institution.

\section{Values-based Management}

The political and non-political arms of government are separate from each other as the political (elected) arm is accountable to the public while the non-political (public service) arm is accountable to the political arm while still maintaining its own codified values. However, there is a need for a balance and recognition between public service values and the values of the governing party. Most importantly, the public service must recognize its role within the broader democratic government by valuing 
the neutral, fair, and inclusive delivery of services to all members of the public. The public service as an institution itself must be devoted to implementing its values within its role (Kernaghan, 2003). A commitment to democracy through these fundamental values should not conflict with the needs of any political party within the Canadian context. The compatibility of public servants with the governing party should not reside within the values of the party itself, but through the values of the public service. The implementation of these values is vital to the professional, representative, non-partisan, and excellent work of public servants.

Kernaghan (2003) emphasizes that values need to be successfully and fully integrated into the public service through values-based leadership. He states that, governments must address the following points in order to conduct effective values-based management:

1. An assessment of current values statement.

2. An assessment of desirability and feasibility of adopting values statements.

3. An implementation strategy through values-based leadership. (p. 718).

Kernaghan (2003) suggests that "leaders must serve not only as exemplary models of values-based behavior, but also skillful practitioners of the art of values management" (p. 718). It is necessary that leaders and senior management encourage the acceptance and integration of codified values into the daily lives of public servants by encouraging broad acceptance.

Through Kernaghan's (2003) model, the public service can assess its current values, assess their feasibility, and implement a strategy to increase values-based leadership with the ultimate goal of a public service that is professional, representative, non-partisan, respectful, and excellent (Clerk of the Privy Council, 2016). A complete adoption and acceptance of public service values will allow for both political and non-political democratic parts of the government to serve their full purpose. Furthermore, with the acceptance of these values by public servants, their sense of accomplishment and motivation should be tied to these values rather than the values of the governing party. Through progressive leadership, the public service should reemphasize their values in order to work successfully with all parts of government including populist and conservative governing parties. Furthermore, the broader acceptance of these public service values should be accepted fully by the political arm of government in order to ensure effective and evidence-based policies and servicedelivery.

\section{Recommendations}

Based on the development of a populist, conservative movement and Kernaghan's (2003) model, the public service should implement the following recommendations:

\section{Recommendation \#1}

Public service management and leaders in the Public Service Commission should assess and consider public service values to ensure they meet the needs of the public service. This assessment should include descriptions of each value with flexibility within each department, but also tangible actions to ensure they are maintained, including team building activities, discussions of values, and a means of 
sharing ideas and concerns. To ensure true acceptance and involvement, both the whole-of government and individual departments would benefit from a value assessment. Generally, this assessment should consider the current condition, the feasibility and desirability of values and potential ways to implement the public service values more fully into daily actions.

\section{Recommendation \#2}

Public service leadership and management should be given training on values-based management within the context of public service values. This training should focus on encouraging the acceptance of public service values within the public service's service delivery function rather than in the context of the current governing party. Values-based leadership and public service success should focus on the achievement of these values through conversations between employees and team building activities.

\section{Recommendation \#3}

Public servants should receive training sessions and information from their management teams on the role of the public service within the broader government and democratic context. These sessions should focus on public service values and their function of service delivery within the context of a democratic institution. Most importantly, the training should focus on open conversations between employees and team building activities for public servants within their own departments and organizations in order to be truly impactful.

\section{Conclusion}

The rise of the populist movement within the Conservative Party presents many concerns for the public service regarding values and motivations within the institution. The rise of conservative populism through Stephen Harper's government has led to resentment and distrust on both the political and public service sides of government. His government cut public service positions, censured government scientists and researchers, and politicized public service management through various actions. Many of these actions correspond with the values of populist conservatism, which is selfinterested and resents bureaucracy. However, many public servants perceive these actions as a threat to the institution of public service. Therefore, the public service needs to focus on motivation and management through values-based leadership in order to encourage tangible actions such as team building and open communication to achieve the values of fair, inclusive, and neutral service delivery. Through an assessment of current public service values, training sessions for leaders on effective values-based management, and sessions for public servants on their role within government, the public service can achieve the ultimate goal of a public service that is professional, representative, nonpartisan, respectful, and excellent, regardless of the governing party. The public service must adapt to the political arm of government, but this adaptation does not require the public service to forget its fundamental role in democracy.

\section{References}

Betz, H.-G ., \& J ohnson, C. (2004). Against the current - stemming the tide: the nostalgic ideology of the contemporary radical populist right. J ournal of Political Ideologies, 9(3), 311-327. doi:

$10.1080 / 1356931042000263546$ 
Clerk of the Privy Council. (2016, J uly). The Public Service of Canada. R etrieved from http://www.clerk.gc.ca/local_grfx/doc s/ps-fp-eng.pdf

Farney, J . (2013). Canadian populism in the era of the united right. In J . Farney \& D. Rayside (Eds.), Conservatism in Canada. Toronto: University of Toronto Press.

Freeman, A. (2015, November 24). Stephen Harper's parting act of contempt for the public service. Retrieved from http://ipolitics.ca/2015/11/24/stephen -harpers-parting-act-of-contempt-forthe-public-service/

Hay, C. (2011). Ideas and the construction of Interests. In D. Béland \& R. H. Cox (Eds.), Ideas and Politics in Social Science Research. Oxford: Oxford University Press.

Kernaghan, K. (2003). Integrating values into public service: the values statement as centerpiece. Public Administration R eview, 63(6), 711 719.

May, K. (2014, November 12). Conservatives have wiped 37,000 off the public-service payroll, cutting jobs faster than expected. National Post. Retrieved from http://news.nationalpost.com/news/c anada/canadianpolitics/conservatives-have-wiped37000-off-the-public-service-payrollcutting-jobs-faster-than-expected

May, K., \& MacLeod, I. (2015, October 7). Bureaucracy baffled by Harper's niqab stance. Ottawa Citizen.

Retrieved from

http://ottawacitizen.com/news/politic s/harper-doubles-down-on-possibleniqab-ban-in-public-service

May, K. (2016, December). Canada's public servants union wins pay hike and will keep controversial sick leave banks in tentative deal. National Post. Retrieved from http://news.nationalpost.com/news/c anada/canadas-public-servantsunion-wins-pay-hike-and-will-keepcontroversial-sick-leave-banks-intentative-deal

Proctor, J . (2016, O ctober 3). CBC-Angus Reid Institute poll: Canadians want minorities to do more to 'fit in'. CBC News. Retrieved from http://www.cbc.ca/news/canada/briti sh-columbia/poll-canadiansmulticulturalism-immigrants-

\subsection{4}

Tasker, J . P. (2016, February 4). Liberals to roll back Tories' $\$ 900 \mathrm{M}$ federal sick leave changes - Politics. CBC News. Retrieved from http://www.cbc.ca/news/politics/feder al-sick-leave-scott-brison-1.3433896

Winter, E. (2015). Rethinking multiculturalism after its "retreat": lessons from Canada. The American Behavioral Scientist, 59(6), 637. 